\title{
The effect of choice-feeding from 7 weeks of age on the production characteristics of laying hens
}

\author{
M. D. Olver and D. D. Malan \\ ARC Animal Nutrition and Animal Products Institute, Private Bag X2, Irene 0062, South Africa
}

\begin{abstract}
Day-old Amberlink pullets were fed chicken starter mash for the first seven weeks of age. Group A was choice-fed with pelleted protein concentrate, whole yellow maize and limestone powder from seven to 16 weeks of age. Group B received the same diet as group A, but the protein concentrate was fed in mash form. Group C (control treatment) received a pullet grower diet in mash form. The pullets were placed in individual laying cages from 16-80 weeks of age. The choicefed groups received feedstuffs from three separate troughs (i.e. whole maize, protein concentrate and limestone powder), and group $\mathrm{C}$ received a layer diet in mash form. Hens offered the choice-fed diets were heavier $(\mathrm{P}<0.05)$ at 16 weeks and at first egg than hens fed the control diet, even though they ate less food (group A: $66.1 \mathrm{~g} / \mathrm{d}$; group B: $66.4 \mathrm{~g} / \mathrm{d}$ ) than the control group (68.2 g/d). During the laying period (16-80 weeks), hens offered the choice-fed diets laid significantly (P $<0.01$ ) heavier eggs, eggs with thicker shells, eggs with darker yolks and had better food conversion ratios than those fed the control diet. No significant differences between treatments were observed for eggs laid per hen, food consumed per day or Haugh unit score. Choice feeding was found to be beneficial for laying hens, and it appeared that early commencement of the regime was necessary for optimum output.
\end{abstract}

Keywords: choice feeding, layers, hens, egg, food conversion ratio, poultry, nutrition

\#Author to whom correspondence should be addressed; E-mail: dmalan@iapi.agric.za

\section{Introduction}

Forbes \& Shariatmadari (1994) and Forbes \& Covasa (1995) reviewed the effects of choice feeding on the performance of laying hens. They reported that both growing and laying birds needed a period of learning before becoming proficient in the selection of feedstuffs. The principle underlying choice feeding of poultry is that individual birds reared in a flock are able to select between various feed ingredients according to individual needs and production capacities. This is not possible when a single conventional food is given. Cumming (1992) and Ciszuk et al. (1998) reported that choice feeding (whole grains plus a protein concentrate and calcium) of layers has financial advantages for rural small-scale poultry production. Where the transport cost of feedstuffs is high and diet-mixing machinery is expensive, as in the case of developing countries, it may be more economical to transport only a protein concentrate and add this to locally grown grains such as maize and sorghum. Locally produced ingredients could be utilised far more efficiently if fed in a free choice system than as a complete diet.

Laying hens are normally fed a mash diet. The use of whole grains would not only save the energy cost of grinding and mixing, but is also accompanied by increased efficiency of food utilisation. McIntosh et al. (1962) showed that grinding or pelleting wheat, barley, oats or maize did not result in a consistent increase in metabolizable energy of poultry feeds. Moreover, they found that whole wheat yielded more metabolizable energy than ground or pelleted wheat in two out of three experiments. Emmans (1977) offered hens either a complete layer mash or a choice between the complete diet and ground barley, and found no difference in performance between the two treatments. Karunajeewa (1978) fed laying hens complete mash diets, either barley or wheat based, or a choice between the whole grains and a concentrate mixture. Hens receiving wheat laid better than those fed barley, but the hens receiving a choice laid heavier eggs and consumed $11 \%$ less food than those given the complete diets. Mongin \& Sauveur (1974) reported that hens increased their calcium intake when ovulation was about to occur during the laying period. Hughes \& Wood-Gush (1971) reported that calcium appetite appeared to be a learned response and that the laying hen has the ability to selectively consume calcium to meet maintenance and production requirements.

The object of this experiment was to compare the production characteristics of Amberlink pullets given a complete diet $v s$. those choice-fed a protein concentrate in either mash or pelleted form in conjunction with whole yellow maize and limestone powder.

\section{Material and methods}

One hundred and eight day-old Amberlink pullets were reared under identical conditions and fed pullet starter mash for the first seven weeks of age. The experiment consisted of two phases: a rearing phase from 7-16 weeks (phase 1) and a laying phase from 16-80 weeks (phase 2). Phase 1 consisted of three experimental diets with three replicates of 12 pullets 
each. In phase 2, each of the three groups consisted of 32 pullets, which were housed, in individual laying cages. In phase 1, birds were housed in nine pens measuring $2 \mathrm{~m} \times 2 \mathrm{~m}$, with wood shavings as litter and one bell-type drinker per pen. Group A was choice-fed with a pelleted protein concentrate, whole yellow maize and limestone powder. Group B received the same as group A except that the protein concentrate was offered in mash form. Groups A and B received their food for the first 3 weeks of phase 1 (7-10 weeks) in the same food trough. Thereafter the food was offered from three separate troughs. Group C was the control treatment and received a mash pullet grower diet from 7-16 weeks (Table 1). All diets contained the same energy and protein sources.

Table 1 Composition of grower diets (7-16 weeks) fed to Amberlink pullets (g/kg).

\begin{tabular}{lcc}
\hline \multicolumn{1}{c}{ Ingredients } & Mash (Diet C) & Concentrate Mix (Diet A \& B) \\
\hline Yellow maize meal & 550.4 & - \\
Wheaten bran & 228.8 & 530.4 \\
Fish meal & 30.0 & 69.5 \\
Soyabean oilcake meal & 153.5 & 355.8 \\
Limestone powder & 18.2 & - \\
Dicalcium phosphate & 12.0 & 27.8 \\
Dl-Methionine & 0.4 & 0.9 \\
Fine salt & 2.7 & 6.3 \\
Vitamin \& mineral premix & 4.0 & 9.3 \\
Calculated composition (as fed) & & \\
True metabolizable energy (MJ/kg) & 11.6 & 8.5 \\
Crude protein & 166.3 & 276.9 \\
Lysine & 8.4 & 16.53 \\
Methionine & 3.4 & 5.59 \\
Methionine \& cystine & 6.5 & 10.27 \\
Tryptophan & 2.1 & 3.73 \\
Calcium & 11.0 & 10.1 \\
Available phosphorus & 4.2 & 8.8 \\
\hline
\end{tabular}

At 16 weeks of age, the pullets were placed in a naturally ventilated laying house in laying cages measuring 400 $\mathrm{mm} \times 500 \mathrm{~mm}$ x $420 \mathrm{~mm}$ with one hen per cage. An empty cage was left between each hen so that no cross feeding could take place. The control pullets received laying mash from 16 weeks until the end of the experiment at 80 weeks of age (Table 2). Groups A and B received food from three separate troughs containing whole yellow maize, protein concentrate (pelleted or mash) and limestone powder. Lighting and vaccination procedures recommended by Amberlink were followed.

Each bird was weighed at 7 weeks, 16 weeks and at first egg. Egg production and egg weight of each hen was recorded daily for sixteen consecutive 28-day periods. The consumption of mash, pellets, maize and limestone for each hen was measured separately on a weekly basis throughout the experiment. An egg from each hen was used for measurement of shell thickness and Haugh unit score (Scott et al., 1982) once every 28-day period. Yolk colour (El Boushy \& Raterink, 1992) was observed using a Roche colour fan from an egg laid by each hen and was recorded during the last 28-day period.

The data were subjected to analysis of variance for a completely randomised design, and means of the treatments were compared by the Bonferroni pairwise comparison method (SAS Institute, 1989). Due to heterogeneous variances of the parameters in Table 5, analysis of variance could not be performed on this data, since analysis of variance requires homogeneity of variances and normality of data. The non-parametric Kruskall-Wallis test (Siegel, 1956) was used to test for significant differences between the treatments at the 5\% significance level. The Kruskall - Wallis procedure assigns ranks to all the values and uses the means of ranks of the treatments to test for differences. 
Table 2 Composition of laying diets (16-80 weeks) fed to Amberlink hens ( $\mathrm{g} / \mathrm{kg})$.

\begin{tabular}{lcc}
\hline \multicolumn{1}{c}{ Ingredients } & Mash (Diet C) & Concentrate Mix (Diet A \& B) \\
\hline Yellow maize meal & 582.1 & - \\
Wheaten bran & 100.5 & 298.1 \\
Fish meal & 30.0 & 88.9 \\
Soyabean oilcake meal & 184.9 & 548.5 \\
Limestone powder & 80.8 & - \\
Dicalcium phosphate & 14.2 & 42.0 \\
Dl-Methionine & 0.6 & 2.0 \\
Fine salt & 2.9 & 9.0 \\
Vitamin \& mineral premix & 4.0 & 12.0 \\
Calculated composition (as fed) & & \\
True metabolizable energy (MJ/kg) & 11.5 & 9.20 \\
Crude protein & 165.0 & 342.75 \\
Lysine & 8.66 & 21.71 \\
Methionine & 3.60 & 7.75 \\
Methionine \& cystine & 6.60 & 13.18 \\
Tryptophan & 1.98 & 4.48 \\
Calcium & 34.00 & 14.13 \\
Available phosphorus & 4.30 & 11.46 \\
\hline
\end{tabular}

\section{Results and discussion}

During the rearing period ( $7-16$ weeks) the pullets offered the choice-fed diets gained more weight $(\mathrm{P}<0.05)$ than those fed the grower diet (Table 3 ). These pullets consumed approximately $7 \mathrm{~g}$ maize per day more than the control pullets, but had a lower food intake. This suggests that the pullets given whole maize were able to utilise dietary energy more efficiently than those given ground maize. This substantiates the finding of McIntosh et al. (1962) that whole grains tend to yield more ME than pelleted or ground grains. The pullets fed the choice diets consumed more than twice the amount of limestone than those offered the complete diet $(2.7 v s .1 .2 \mathrm{~g} / \mathrm{d})$.

Table 3 The effect of the rearing diet (7-16 weeks) on body weight, weight of first egg and days to first egg (mean \pm s.d.)

\begin{tabular}{lccc}
\hline & $\begin{array}{c}\text { Maize, calcium and } \\
\text { pelleted concentrate }\end{array}$ & $\begin{array}{c}\text { Maize, calcium and } \\
\text { mash concentrate }\end{array}$ & Mash diet \\
\hline Food intake $(\mathrm{g} / \mathrm{d})$ & $66.1^{*}$ & $66.4^{* *}$ & $68.2^{* * *}$ \\
7 Week body weight $(\mathrm{g})$ & $606.8 \pm 32.3^{\mathrm{a}}$ & $606.7 \pm 39.0^{\mathrm{a}}$ & $608.1 \pm 30.5^{\mathrm{a}}$ \\
16 Week body weight $(\mathrm{g})$ & $1431.8 \pm 90.8^{\mathrm{b}}$ & $1427.1 \pm 91.2^{\mathrm{b}}$ & $1379.9 \pm 76.6^{\mathrm{a}}$ \\
Weight at first egg (g) & $1853.4 \pm 85.6^{\mathrm{b}}$ & $1850.3 \pm 91.2^{\mathrm{b}}$ & $1800.1 \pm 89.6^{\mathrm{a}}$ \\
Weight of first egg (g) & $43.3 \pm 3.9^{\mathrm{a}}$ & $43.8 \pm 5.8^{\mathrm{a}}$ & $41.3 \pm 5.9^{\mathrm{a}}$ \\
Days to first egg & $137.5 \pm 8.4^{\mathrm{a}}$ & $139.0 \pm 6.3^{\mathrm{a}}$ & $139.0 \pm 9.3^{\mathrm{a}}$ \\
\hline
\end{tabular}

${ }^{\mathrm{a}, \mathrm{b}}$ Means within rows with different superscripts are significantly different $(\mathrm{P}<0.05)$; ${ }^{*}$ maize, $44.9 \mathrm{~g} ;$ protein concentrate, $18.5 \mathrm{~g}$; limestone, $2.7 \mathrm{~g} ;{ }^{* *}$ maize, $43.8 \mathrm{~g}$; protein concentrate, $19.9 \mathrm{~g}$; limestone, $2.7 \mathrm{~g} ;{ }^{* * *}$ maize, $37.5 \mathrm{~g}$; protein concentrate, $29.4 \mathrm{~g}$; limestone, $1.2 \mathrm{~g}$

It is well known that the amount of calcium fed to pullets prior to the onset of laying will influence the efficiency of utilization of calcium during lay. Meyer et al. (1970) reported that extra calcium was needed for medullary bone development and that calcium intake increased slowly prior to the first egg. The increased calcium intake observed by the pullets during the rearing period (7-16 weeks) could have been responsible for the increased weight of the first eggs laid by the choice-fed pullets $(\mathrm{P}<0.05)$, as could the heavier body weights $(\mathrm{P}<0.05)$ of these pullets when the eggs were laid. The pullets fed the complete diet also consumed a greater amount of protein than choice-fed pullets, and thus the cost during rearing would be higher.

The effects of the diets on hen performance (16-18 weeks) are shown in Table 4. The hens offered a choice did not lay more eggs, nor did they consume more food than those fed a complete mash diet. However, the hens offered the choice-fed diet laid heavier eggs and eggs with thicker shells $(\mathrm{P}<0.01)$ than those fed the complete diet. The heavier egg size of the choice-fed hens accounted for the better $(\mathrm{P}<0.01)$ food conversion ratio obtained by these hens compared to 
those fed the complete diet. The Haugh unit scores of eggs did not differ $(\mathrm{P}>0.05)$ between diets, but the yolk colour of eggs laid by choice-fed hens was darker $(\mathrm{P}<0.01)$ than that of eggs laid by hens fed the complete mash diet.

Table 4 The effect of laying diet on egg production, egg quality traits and yolk colour (mean \pm s.d.) from 16-80 weeks of age

\begin{tabular}{lccc}
\hline & $\begin{array}{c}\text { Maize, calcium and } \\
\text { pelleted concentrate }\end{array}$ & $\begin{array}{c}\text { Maize, calcium and } \\
\text { mash concentrate }\end{array}$ & Mash diet \\
\hline Food intake (g/hen/day) & $116.50 \pm 3.80^{\mathrm{a}}$ & $116.80 \pm 2.9^{\mathrm{a}}$ & $118.50 \pm 2.20^{\mathrm{a}}$ \\
Food conversion ratio (kg feed /kg eggs) & $2.32 \pm 0.14^{\mathrm{a}}$ & $2.33 \pm 0.18^{\mathrm{a}}$ & $2.54 \pm 0.17^{\mathrm{b}}$ \\
Eggs / hen & $343 \pm 25^{\mathrm{a}}$ & $347 \pm 27^{\mathrm{a}}$ & $342 \pm 28^{\mathrm{a}}$ \\
Egg weight $(\mathrm{g})$ & $61.9 \pm 3.6^{\mathrm{a}}$ & $61.1 \pm 3.0^{\mathrm{a}}$ & $57.8 \pm 3.8^{\mathrm{b}}$ \\
Shell thickness $(\mu \mathrm{m})$ & $35.2 \pm 1.6^{\mathrm{a}}$ & $35.3 \pm 1.9^{\mathrm{a}}$ & $32.5 \pm 1.5^{\mathrm{b}}$ \\
Haugh unit score & $100.31 \pm 3.57^{\mathrm{a}}$ & $100.98 \pm 3.23^{\mathrm{a}}$ & $100.57 \pm 2.66^{\mathrm{a}}$ \\
Yolk colour score (Roche colour fan) & $7.8 \pm 1.0^{\mathrm{a}}$ & $7.7 \pm 1.0^{\mathrm{a}}$ & $5.8 \pm 0.9^{\mathrm{b}}$ \\
\hline
\end{tabular}

${ }^{\mathrm{a}, \mathrm{b}}$ Means within rows with different superscripts are significantly different $(\mathrm{P}<0.01)$.

Karunajeewa (1978) also observed that egg yolk colour was increased when hens received whole grain plus concentrate. El Boushy \& Raterink (1992) reported that maize contains rich colour pigments which leads to the production of eggs with reasonable yolk colour. However, they reported that the effect on yolk colour of whole grain and concentrate mixtures offered on a free choice basis has not been fully investigated. Quackenbush (1963) found that storage can cause a considerable loss of the carotenoid pigments, whereas Leeson \& Summers (1997) reported that natural pigments in cereals tend to decline with prolonged storage, with up to $50 \%$ loss reported at elevated temperatures. The maize used in this experiment (diet C) was ground from the same batch of whole maize used in diets A and B. Since the choice-fed hens ate less yellow maize and less protein concentrate, they would have consumed fewer pigments. The reason for the darker yolks in choice-fed hens can possibly be ascribed to a more rapid deterioration of pigments when the maize is ground compared to whole maize. The effects of diet on food consumed in laying hens from 16-80 weeks of age are shown in Table 5.

Table 5 The effect of diet on the daily food consumption in laying hens from 16-80 weeks of age

\begin{tabular}{lccc}
\hline & $\begin{array}{c}\text { Maize, calcium and } \\
\text { pelleted concentrate }\end{array}$ & $\begin{array}{c}\text { Maize, calcium and } \\
\text { mash concentrate }\end{array}$ & *Mash diet \\
\hline Maize $(\mathrm{g})$ & $66.60 \pm 3.04^{\mathrm{b}}$ & $65.57 \pm 2.68^{\mathrm{b}}$ & $68.98 \pm 1.30^{\mathrm{a}}$ \\
Protein concentrate $(\mathrm{g})$ & $34.41 \pm 2.25^{\mathrm{a}}$ & $36.19 \pm 2.19^{\mathrm{a}}$ & $39.95 \pm 0.75^{\mathrm{b}}$ \\
Limestone powder $(\mathrm{g})$ & $15.49 \pm 0.86^{\mathrm{b}}$ & $15.04 \pm 1.12^{\mathrm{b}}$ & $9.57 \pm 0.18^{\mathrm{a}}$ \\
ME intake (MJ) & $1.26 \pm 0.04^{\mathrm{a}}$ & $1.26 \pm 0.04^{\mathrm{a}}$ & $1.36 \pm 0.03^{\mathrm{b}}$ \\
Protein intake $(\mathrm{g})$ & $17.49 \pm 0.78^{\mathrm{a}}$ & $18.10 \pm 0.51^{\mathrm{a}}$ & $19.55 \pm 0.37^{\mathrm{b}}$ \\
Calcium intake $(\mathrm{g})$ & $6.38 \pm 0.34^{\mathrm{b}}$ & $6.24 \pm 0.44^{\mathrm{b}}$ & $4.03 \pm 0.08^{\mathrm{a}}$ \\
\hline
\end{tabular}

${ }^{\mathrm{a}, \mathrm{b}}$ Means within rows with different superscripts are significantly different $(\mathrm{P}<0.05)$; ${ }^{*}$ Calculated from feed composition shown in Table 2 .

Hens offered the choice-fed diet laid heavier eggs than those fed the mash diet (Table 4) despite the fact that they consumed less energy and protein compared to the hens offered the mash diet (Table 5). These results are at variance with the finding that increased protein intake results in heavier eggs (Scott et al., 1982). However, both Blair et al. (1973) and Karunajeewa (1978) reported heavier eggs from the choice-fed hens that also consumed less energy and protein. In the present study, the choice-fed hens had a greater calcium intake than those fed the mash diet. This, coupled with differences $(\mathrm{P}<0.01)$ in egg shell thickness would indicate that the increased egg mass was due to increased calcium intake. Neither Blair et al. (1973) nor Karunajeewa (1978) measured shell thickness, but they recorded calcium intakes of 3.30 and 3.65 $\mathrm{g}$ per hen per day respectively, which were lower than the intakes of 6.38 and $6.24 \mathrm{~g} / \mathrm{hen} / \mathrm{d}$ observed for choice-fed hens in this experiment. Classen \& Scott (1982) observed that hens with a calcium intake of $4.82 \mathrm{~g} / \mathrm{d}$ laid heavier eggs than hens that consumed $3.68 \mathrm{~g} / \mathrm{d}(53.5 \mathrm{vs} .51 .2 \mathrm{~g} / \mathrm{egg})$. Since the increased calcium intake of the choice-fed hens in the present experiment led to thicker shells it is possible that the heavier eggs produced by the choice-fed hens were due to their higher calcium intake. Carter (1971) estimated that egg breakages in the UK represent a financial loss equivalent to R35 million, and Hamilton (1982) estimated the loss in the USA and Canada to be equivalent to R440 million. We have observed that intake of limestone powder was negligible in some cases when Amberlink hens are fed a choice diet at point-of-lay (20 weeks), resulting in many thin-shelled eggs. The results of this study suggest that the incidence of egg breakages may be 
reduced if hens are choice-fed from an early age, especially with regard to the calcium source.

\section{Conclusions}

The observed improvements of choice feeding in laying hens offered whole maize, protein concentrate and calcium can be attributed to the greater dietary flexibility which allowed the hens to meet peak energy, protein and calcium demands during egg formulation and this allowed a more efficient utilization of nutrients. It is recommended that choice feeding should start at an early age.

\section{References}

Blair, R., Dewar, W.A. \& Downie, J.N., 1973. Egg production responses of hens given a complete mash or unground grain together with concentrate pellets. Br. Poult. Sci. 14, 373.

Carter, T.C., 1971. The hen's egg: Shell cracking at oviposition in battery cages and its inheritance. Br. Poult. Sci. 12, 259.

Ciszuk, P., Charpentier, L. \& Hult, E., 1998. Free choice of feed for ecological hens. FAKTA, Jordbruk. Sammanfattar aktuell forskning vid SLU. Nr. 7.

Classen, H.L. \& Scott, T.A., 1982. Self-selection of calcium during the rearing and early laying periods of White Leghorn pullets. Poult. Sci. 61, 2065.

Cumming, R.B., 1992. The advantages of free choice feeding for village chickens. Proceedings of the 19th World's Poultry Congress p. 627.

El Boushy, A. R. \& Raterink, R., 1992. Egg yolk pigmentation. World. Rev. Anim. Prod. 27, 50-62.

Emmans, G.C., 1977. The nutrient intake of laying hens given a choice of diets, in relation to their production requirements. Br. Poult. Sci. 18, 227.

Forbes, J.M. \& Shariatmadari, F., 1994. Diet selection for protein by poultry. World's Poult. Sci. J. Vol. 50, March, 7.

Forbes, J.M. \& Covasa, M., 1995. Application of diet selection by poultry with particular reference to whole cereals. World's Poult. Sci. J. Vol. 51, July, 149.

Hamilton, R.M.G., 1982. Methods and factors that affect the measurement of egg shell quality. Poult. Sci. 61, 2022.

Hughes, B. O. \& Wood-Gush, D. G. M., 1971. A specific appetite for calcium in domestic chickens. Anim. Behav. 19, 490-499.

Karunajeewa, H., 1978. The performance of Cross-bred hens given free choice feeding of whole grains and a concentrate mixture and the influence of source of xantophylls on yolk colour. Br. Poult. Sci. 19, 699.

Leeson, S. \& Summers, J. D., 1997. Commercial Poultry Nutrition. Second Edition. University Books, Guelph, Canada.

McIntosh, J.I., Slinger, S.J., Sibbald, I.R. \& Ashton, G.C., 1962. Factors affecting the metabolizable energy content of poultry feeds. 7. The effect of grinding, pelleting and grit feeding on the availability of the energy of wheat, corn, oats and barley. 8. A study on the effects of dietary balance. Poult. Sci. 41, 445.

Meyer, G. B., Babcock, S. W. \& Sunde, M. L., 1970. Decreased feed consumption and increased calcium intake associated with pullet's first egg. Poult. Sci. 49, 1164-1169.

Mongin, P. \& Sauveur, B., 1974. Voluntary food and calcium intake by the laying hen. Br. Poult. Sci. 15, 349-359.

Quakenbush, F W., 1963. Corn carotenoids: effects of temperature and moisture on losses during storage. Cereal Chem. 40, 266-269.

SAS,1989. SAS User's Guide : Statistics. SAS Institute Inc., Cary, NC.

Scott, M.L., Nesheim, M.C. \& Young, R.J., 1982. Nutrition of the chicken. Third Edition. M. L. Scott and Associates, Ithaca, New York.

Siegel, S., 1956. Non-parametric statistics for the behavourial sciences. McGraw-Hill Book Co. Inc., New York. 